\section{References}

${ }^{1}$ Harpur, J E, et al, Lancet, 1971, 2, 1331.

${ }^{2}$ Royston, G R, British Heart fournal, 1972, 34, 526.

${ }^{3}$ Moyer, J B, Hiller, G I, and Detroit, M, American Heart fournal, 1951, 41, 340.

${ }^{4}$ Groden, B M, Allison, A, and Shaw, G B, Scottish Medical fournal, 1967, $12,435$.

${ }^{5}$ Adgey, A A J, British Heart fournal, 1969, 31, 750.

${ }^{6}$ Hutter, A M, et al, New England fournal of Medicine, 1973, 288, 1141.

${ }^{7}$ Tucker, H H, et al, British Medical fournal, 1973, 1, 10.

${ }^{8}$ Hayes, M J, Morris, G K, and Hampton, J R, British Heart fournal, 1974, 36, 395.
${ }^{9}$ Chaturvedi, N C, et al, British Heart fournal, 1974, 36, 533.

10 Restieaux, N, et al, Lancet, 1967, 1, 1285.

11 Thompson, P, and Sloman, G, British Medical fournal, 1971, 4, 136.

12 Grace, W J, and Yarvote, P M, Chest, 1971, 59, 15.

${ }^{13}$ Reynell, P C, British Heart fournal, 1975, 37, 166.

14 Soler, N G, et al, Lancet, 1974, 1, 475.

15 Bradley, R F, and Bryfogle, J W, American fournal of Medicine, 1956, 20, 207.

${ }^{16}$ Partamian, J O, and Bradley, R F, New England Journal of Medicine, 1965, 273, 455.

17 Harrower, A D B, and Clarke, B F, British Medical fournal, 1976, 1, 126.

\title{
Nitrazepam: lastingly effective but trouble on withdrawal
}

\author{
KIRSTINE ADAM， LIISI ADAMSON， VLASTA BŘEZINOVÁ, WILLIAM M HUNTER, \\ IAN OSWALD
}

British Medical fournal, 1976, 1, 1558-1560

\section{Summary \\ The sleep of 10 volunteers with an average age of 57 years was recorded electrophysiologically before, during, and after nitrazepam $5 \mathrm{mg}$ nightly for 10 weeks. Sleep was longer and less broken on the drug and no tolerance was obvious after two months' use. Withdrawal of the drug, however, caused sleep to be temporarily worse than before the drug had been taken. Slow-wave sleep was reduced by nitrazepam, but the accompanying secretion of growth hormone was not impaired.}

\section{Introduction}

We recently described how a placebo had no effect on sleep ${ }^{1}$; here, using the same 10 middle-aged volunteers, we report on the actions of nitrazepam $5 \mathrm{mg}$. We also looked for any influence on the nocturnal secretion of growth hormone $(\mathrm{GH})$.

All-night electrophysiological recording makes precise measurement of the amount of time a person is asleep possible. It also shows two different kinds of sleep that alternate through the night. One is rapid eye movement (REM) or paradoxical sleep, the other is non-REM or orthodox sleep. The latter is subdivided into stages $1,2,3$, and 4 . Stages 3 and 4 are known as slow-wave sleep (SWS) and during these stages the large nocturnal secretion of $\mathrm{GH}$ occurs. In the undrugged condition the secretion depends on the presence of stages 3 and 4 and does not take place if these stages are not allowed to develop. ${ }^{2}{ }^{3}$ Growth hormone is thought to be important for sleep's restorative function, and since many benzodiazepines will reduce SWS, it seemed important to find out whether nitrazepam would impair GH secretion. In clinical practice drugs are taken for long periods, and so we conducted a study over many weeks.

\footnotetext{
Sleep Laboratory, University Department of Psychiatry, Royal Edinburgh Hospital, Edinburgh EH10 5HF

KIRSTINE ADAM, BSC, research associate LIISI ADAMSON, licentiate in medicine, research fellow VLASTA BŘEZINOVÁ, MD, PHD, research psychiatrist IAN OSWALD, DSC, FRCPSYCH, reader in psychiatry

\section{Methods}

Ten volunteers, with the agreement of their general practitioners, took part in this study of nitrazepam $5 \mathrm{mg}$ nightly. There were six women and four men aged 41-62 (mean 57) years. They had taken no drugs in the preceding months and were asked not to take any drugs other than those given by us and to consume no alcohol. Subjects attended the laboratory, to sleep in quiet and comfortable bedrooms according to the experimental design:

$\begin{array}{llll}\text { Weeks } 1 \text { and } 2 \ldots & \ldots & 2 \text { Adaptation nights, } 6 \text { baseline nights } \\ \text { Weeks } 5 \text { and } 6 \ldots & \ldots & 1 \text { Adaptation night, } 6 \text { early drug nights } \\ \text { Weeks } 7 \text { to } 10 \ldots & \ldots & \text { Drug continued at home } \\ \text { Weeks } 11 \text { and } 12 \ldots & \ldots & \text { 1 Adaptation night, } 6 \text { late drug nights } \\ \text { Weeks } 13 \text { and } 14 \ldots & \ldots & \text { Drug continued at home } \\ \text { Weeks } 15 \text { and } 16 \ldots & \ldots & 1 \text { Adaptation night, } 6 \text { withdrawal nights }\end{array}$

The drug was taken 30 minutes before lights-out (about 2230 to 0715). On all nights the electroencephalogram, eye movements, and submental muscle tone were recorded.

Seven of the volunteers attended the laboratory for six additional nights, when blood was sampled through a catheter without disturbing the sleeper. ${ }^{4}$ The six nights represented one adaptation night followed by one recording and blood sampling night during the baseline period and similarly one adaptation and one measurement night in the early drug phase and one adaptation and one measurement night in the late drug period. The blood samples were taken every 30 minutes, and the plasma was separated and stored deep-frozen until assayed.

The GH concentration in each sample was assayed "blind" as to the experimental condition by the MRC Radioimmunoassay Team in Edinburgh using the method of Hunter.; The GH results were expressed as $\mathrm{mU} / 1$ (in terms of human growth hormone international reference preparation $66 / 217$ ) concentration at the clock time when the blood sample was taken. These clock times were then converted, for each night, into time in minutes after the first onset of sleep. Graphs were plotted, and the area under the GH curve, from sleep onset to six hours later, was measured by a planimeter in $\mathrm{cm}^{2}$. The vertical scale was $1 \mathrm{~cm} / 2 \mathrm{mU} / 1$ and the horizontal scale was $2 \mathrm{~cm} /$ hour.

The electrophysiological recordings were coded and categorised "blind" into the different stages of sleep and wakefulness." The time it took subjects to fall asleep, the total amount of time they slept, and the hourly distribution and total number of minutes after the onset of sleep that they were awake and in each of the sleep stages were calculated.

STATISTICs-Friedman's analysis of variance was used to test the overall significance of the results ${ }^{\bar{i}}$ and $t$ tests for paired observations were used to compare the different periods of the experiment. ${ }^{8}$

\section{Results}

The volunteers slept longer while taking the drug. This improvement in sleep was maintained throughout the drug period, but on withdrawal from the drug the time spent asleep was significantly shorter than before the drug had been taken (table I). 
TABLE $\mathrm{I}-$ Total time asleep in 10 subjects during six nights in each condition

\begin{tabular}{|c|c|c|}
\hline Condition* & $\begin{array}{c}\text { Mean (: SE of mean) } \\
\text { time asleep (min) }\end{array}$ & $\begin{array}{c}\text { Compared with baseline } \\
(\mathrm{Df}=9)\end{array}$ \\
\hline $\begin{array}{l}\text { Baseline } \\
\text { Early drug } \\
\text { Late drug } \\
\text { Withdrawal }\end{array}$ & $\begin{array}{l}446.9=10 \cdot 8 \\
471 \cdot 0 \div 7.9 \\
469 \cdot 1=8.5 \\
428.7=12.9\end{array}$ & $\begin{array}{l}t=2.50 ; \mathrm{P}<0.025, \text { one-tailed } \\
t=2.97 ; \mathrm{P}<0.01, \text { one-tailed } \\
t=2.61 ; \mathrm{P}<0.025, \text { one-tailed }\end{array}$ \\
\hline
\end{tabular}

*Overall significance of differences among conditions: $\mathrm{Df}=3 ; \%_{\mathrm{r}}^{2}=20.04 ; \mathrm{P}<0.001$.

Intervening wakefulness was still significantly reduced after eight weeks of nitrazepam administration (Df $=9 ; t=1.83 ; \mathrm{P}<0.05$, 1-tailed) (fig 1). A similar reduction had been present during the early drug period ( $\mathrm{Df}=9 ; t=2.25 ; \mathrm{P}<0.05,1$-tailed), and the early and late drug periods did not differ significantly from each other. Withdrawal from the drug increased intervening wakefulness when compared with baseline values, (fig 1). We used the means for each hour, in so far as such data was available, but the fact that sometimes total sleep was very much reduced (in one case to 42 minutes) made statistical assessment of these particular data impracticable.

The amount of time awake, between first falling asleep and before lights-on in the morning, was significantly higher during the withdrawal period and considerably higher two nights after the last dose of

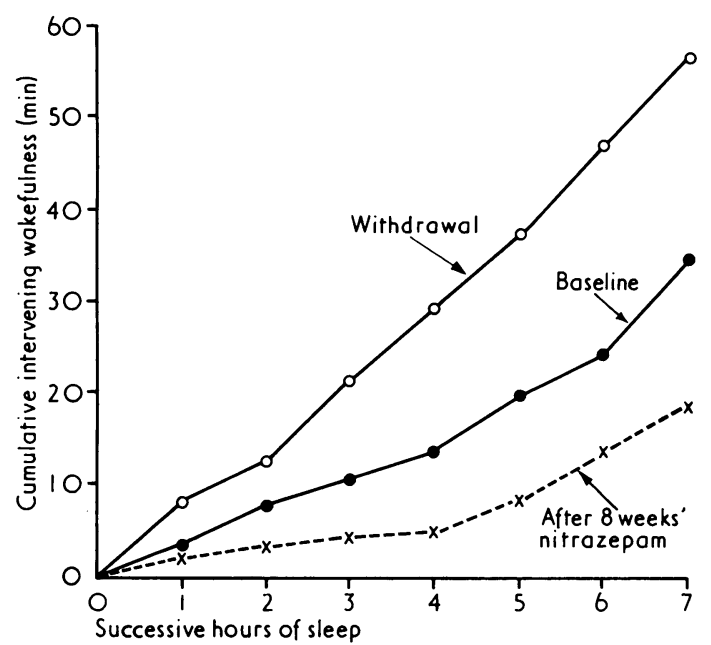

FIG 1-Mean cumulative minutes of wakefulness intervening during the sleep of 10 volunteers.

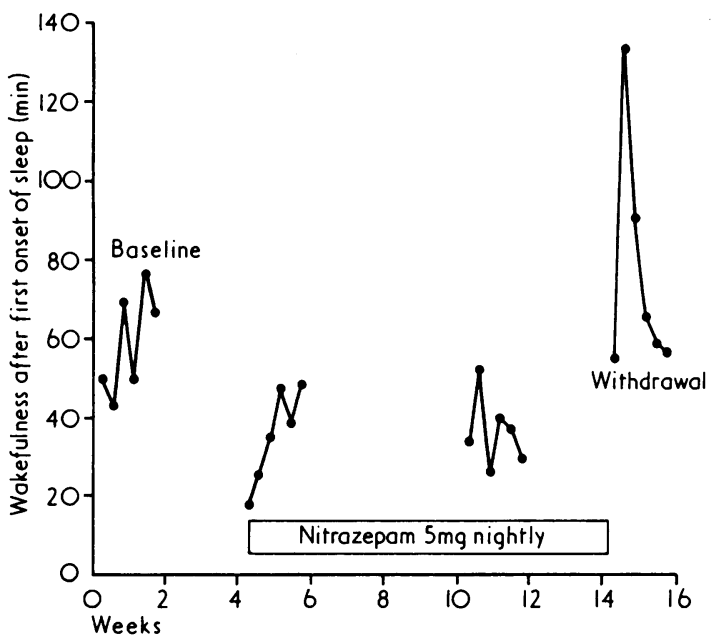

FIG 2-Mean total wakefulness recorded after first onset of sleep in 10 subjects. Overall significance of difference among four conditions: $\%^{2}=19 \cdot 17$; Df $=3 ; \mathrm{P}<0.001$.

Baseline $v$ early drug; Df $=9 ; t=3.24 ; \mathrm{P}<0.01$ (1-tailed).

Baseline $v$ late drug: Df $=: 9 ; t=3.50 ; \mathrm{P}<0.005$ (1-tailed).

Baseline $v$ withdrawal: $\mathrm{Df}=9 ; t=1.87 ; \mathrm{P}<0.05$ (1-tailed) nitrazepam (fig 2). The time it took subjects to fall asleep was not significantly changed.

During the early drug period reduction in REM sleep occurred almost exclusively within the first three hours of sleep. This significant early night reduction was still present in the late drug period. As table II shows, however, by the late drug period a significant increase in REM sleep had appeared in the later night (hours 4-7 of sleep).

TABLE II-Total REM sleep (minutes) accumulated in successive hours of sleep in 10 volunteers. Results are means $\pm S E$ of mean

\begin{tabular}{l|l|l|l} 
& $\begin{array}{c}\text { Early night } \\
\text { Condition }\end{array}$ & $\begin{array}{c}\text { Late night } \\
(1-3 \text { hours })\end{array}$ & $\begin{array}{c}\text { First 7 hours } \\
\text { of sleep }\end{array}$ \\
\hline Baseline & $26 \cdot 2 \pm 3 \cdot 3$ & $59 \cdot 3 \pm 3 \cdot 5$ & $85 \cdot 5 \pm 5 \cdot 3$ \\
Early drug & $16.3 \pm 2 \cdot 6+$ & $58 \cdot 5 \pm 2 \cdot 9$ & $74.8 \pm 4 \cdot 6^{+}$ \\
Late drug & $18 \cdot 6 \pm 2 \cdot 8^{*}$ & $65 \cdot 8 \pm 2 \cdot 9^{*}$ & $84.4 \pm 5 \cdot 1$ \\
Withdrawal & $26.5 \pm 2 \cdot 6$ & $57 \cdot 0 \pm 3 \cdot 7$ & $83.5 \pm 5 \cdot 8$ \\
\hline
\end{tabular}

*Significant difference from baseline, $\mathrm{P}<0.05$ (2-tailed).

+ Significant difference from baseline, $\mathrm{P}<0.01$ (2-tailed).

The mean duration of SWS accumulated in the first six hours of sleep (table III) was significantly reduced during early and late drug administration when compared with baseline levels. The mean values recorded during the late drug period were significantly lower than those of the early drug period ( $\mathrm{Df}=9 ; t=2 \cdot 40 ; \mathrm{P}<0 \cdot 05,2$-tailed). There was a return to baseline levels during the withdrawal period. During drug administration, however, there was no associated decline in GH secretion, but rather a tendency for higher (not significant) levels during drug administration. Friedman's non-parametric analysis of variance by ranks was used to compare the areas under the growth hormone curves. The mean areas ( \pm SE of mean) under the growth hormone curves were: baseline $9.3 \pm 1.7 \mathrm{~cm}^{2}$; early drug $12.3 \pm 2.6$ $\mathrm{cm}^{2}$; late drug $18.3 \pm 4.8 \mathrm{~cm}^{2}\left(\varkappa_{\mathrm{r}}^{2}=3.71 ; \mathrm{Df}=2\right.$; not significant $)$.

TABLE III-Total SWS in first six hours of sleep in 10 volunteers

\begin{tabular}{|c|c|c|}
\hline Condition* & $\begin{array}{c}\text { Mean ( } \\
\text { SWS (min) }\end{array}$ & $\begin{array}{c}\text { Compared with baseline } \\
(\mathrm{Df}=9)\end{array}$ \\
\hline $\begin{array}{l}\text { Baseline } \\
\text { Early drug } \\
\text { Late drug } \\
W^{\prime} \text { ithdrawal }\end{array}$ & $\begin{array}{l}79 \cdot 0 \div 10.5 \\
61.3 \div 10.7 \\
49.9 \div 10.6 \\
72.7 \pm 10.0\end{array}$ & $\begin{array}{l}t=4.22 ; \mathrm{P}<0.01,2 \text {-taile } \\
t=4.34 ; \mathrm{P}<0.01,2 \text {-tailed } \\
t=1.42 ; \text { not significant }\end{array}$ \\
\hline
\end{tabular}

*Overall significant difference among conditions: $\mathrm{Df}=3 ; \chi_{\mathrm{r}}^{2}=14.88 ; \mathrm{P}<0.005$.

\section{Discussion}

As we grow older, we sleep less, and sleep is more broken by periods of wakefulness ${ }^{9-12}$ and, perhaps as a consequence, there is an age-related increase in the consumption of sleeping pills. ${ }^{13}$ Our volunteers were of an older age group and representative of patients who most often complain of inadequate sleep. The maintenance of nitrazepam's action in still reducing the amount of wakefulness after two months of use is parallelled by that of flurazepam when studied during two weeks of drug administration, but contrasts with the diminishing effectiveness of chloral hydrate $(1000 \mathrm{mg})$ or glutethimide $(500 \mathrm{mg}) .{ }^{14}$ The longer drugtaking period in our study was more likely to show any tolerance effects.

We found that nitrazepam reduced the amount of REM sleep in the first three hours of sleep and that, during chronic administration, a late-night REM sleep rebound developed. This REM sleep rebound in the later night during protracted use of hypnotics has been reported for barbiturates. ${ }^{15}$ The lack of REM sleep rebound after withdrawal contrasts with that which is present after larger doses. ${ }^{16} 17$

The decrease in the amount of SWS has been found during chronic intake of other benzodiazepines-for example, flurazepam, ${ }^{1.5}$ chlordiazepoxide, ${ }^{18}$ diazepam, ${ }^{19}$ and fosazepam. ${ }^{20}$ The lack of any associated decrease in the blood level of GH suggests that the metabolic functions associated with SWS may not be impaired by nitrazepam administration. 
The poor sleep caused by stopping nitrazepam is a further reminder of how such drugs create conditions that lead to perpetuation of intake. Patients should be told that after giving up nitrazepam $5 \mathrm{mg}$ or similar drugs they may experience an increase in wakefulness for a week or two, with one or two nights of little sleep. They should be reassured that this disrupted sleep is a temporary consequence of their dependence on the drug that has been withdrawn and that as the weeks pass their sleep will improve again.

We thank Beecham Products Ltd for their help.

\section{References}

1 Adam, K, et al, British Medical fournal, 1976, 1, 195.

2 Sassin, J F, et al, Life Sciences, 1969, 8, part 1, 1299.

3 Schnure, J J, et al, fournal of Clinical Endocrinology and Metabolism, 1971, 33, 234.

${ }^{4}$ Ogunremi, O O, et al, British Medical fournal, 1973, 2, 202.
${ }^{5}$ Hunter, W M, Technique Radioimmunologique, (editor). G Rosselin. Paris, Centre de Recherches INSERM, Hôpital St Antoice, 1972.

${ }^{6}$ Rechtschaffen, A, and Kales, A, (editors), Manual of Standardized Terminology, Techniques and Scoring System for Sleep Stages of Human Subjects. Washington, US Government Printing Office, 1968.

${ }^{7}$ Winer, B J, Statistical Principles in Experimental Design. New York, McGraw-Hill, 1971.

${ }^{8}$ Ferguson, G A, Statistical Analysis in Psychology and Education. New York, McGraw-Hill, 1959.

${ }^{9}$ Feinberg, I, et al, Journal of Psychiatric Research, 1967, 5, 107.

${ }^{10}$ Feinberg, I, Comprehensive Psychiatry, 1968, 9, 138.

11 Williams, R L, et al, EEG of Human Sleep. New York, Wiley, 1974.

12 Błezinová, V, Electroencephalography and Clinical Neurophysiology, 1975, 39, 273.

${ }^{13}$ Dunnell, K, and Cartwright, A, Medicine Takers, Prescribers and Hoarders. London, Routledge and Kegan Paul, 1972.

${ }^{14}$ Kales, A, et al, Archives of General Psychiatry, 1970, 23, 226.

${ }^{15}$ Kales, A, et al, Archives of General Psychiatry, 1970, 23, 211.

${ }_{16}^{16}$ Oswald, I, and Priest, R G, British Medical fournal, 1965, 2, 1093.

17 Kales, A, et al, Archives of General Psychiatry, 1970, 23, 219.

18 Hartmann, E, and Cravens, J, Psychopharmacologia, 1973, 33, 233.

19 Fisher, C, et al, Archives of General Psychiatry, 1973, 28, 252.

${ }^{20}$ Allen, S, and Oswald, I, British .7ournal of Clinical Pharmacology, 1976, 3,165 .

\title{
Comparative study of short-term recovery of mental efficiency after anaesthesia
}

\author{
J E P SIMPSON, C J GLYNN, A G COX, SIMON FOLKARD
}

British Medical fournal, 1976, 1, 1560-1562

\section{Summary}

Two common general anaesthetic techniques were compared to evaluate the time taken for the patient's mental efficiency to recover sufficiently for him to be escorted home after inguinal herniorrhaphy. Recovery in performance efficiency to at least $60 \%$ of the patient's own maximum is suggested as a criterion for discharge, and this needs a stay in hospital of seven to nine hours.

\section{Introduction}

It is a long-established practice to allow some patients home within hours of receiving a short general anaesthetic for minor surgery. Recently this practice has been extended to operations for hernia and varicose veins that have longer periods of anaesthesia and an increase in operative trauma. ${ }^{1}$ We compared two common general anaesthetic techniques to evaluate the time taken for recovery sufficient to allow the patient to be escorted home. Unlike previous related studies ${ }^{2}{ }^{3}$ the time base was in hours and the investigation took account of several factors including the age of the patient, length of operation, nature of surroundings, and circadian variation in mental ability.

Northwick Park Hospital, Harrow, Middlesex HA1 3UJ

J E P SIMPSON, BM, FRCS, surgical registrar

C J GLYNN, MB, FFARCS, anaesthetic registrar

A G COX, MD, FRCSED, consultant surgeon

MRC Perceptual and Cognitive Performance Unit, University of Sussex

SIMON FOLKARD, BSC, PHD, research psychologist

\section{Patients and methods}

Thirty men were admitted on Friday evenings for unilateral inguinal herniorrhaphy. The purpose of the trial had been explained, and after specific instruction they practised the tests to be used in the study before consenting to undertake them every four hours for the next 10 days.

On the next Monday they underwent herniorrhaphy at hourly intervals from 0930 to 1230 , the operation time varying from 29 to 49 minutes (mode 35 minutes). The anaesthetic techniques are summarised in table I. Premedication and induction with thiopentone was similar for every patient, after which one group received a nitrous oxide-oxygen inhalation with fentanyl analgesia (fentanyl anaesthetic) and the other group inhaled halothane, nitrous oxide, and oxygen (halothane anaesthetic). There was no statistically significant difference between the subgroups in either age (mean 50 years; range 29-68 years) or weight (mean $72 \mathrm{~kg}$; range $49-98 \mathrm{~kg}$ ).

Three objective tests of performance efficiency were used in the trial, each reflecting a different type of ability. The tests were administered four times a day at 0800,1200,1600, and 2000, and each involved five three-minute episodes on each occasion (fig 1).

TABLE I-Anaesthetic techniques. The same technique was used throughout each list; on five mornings the anaesthetic was fentanyl and on three mornings it was halothane

Premedication one hour before surgery with papaveretum $20 \mathrm{mg}$ and hyoscine $0.4 \mathrm{mg}^{*}$

\begin{tabular}{|c|c|}
\hline "Fentanyl" ( $(n=18)$ & "Halothane" $(n=12)$ \\
\hline $\begin{array}{l}\text { Thiopentone } 250 \mathrm{mg} \\
\text { Pancuronium } 6 \mathrm{mg} \\
4^{\text {" }} \text { Lignocaine spray } \\
\text { Cuffed Magill tube } \\
\text { Mapleson D circuit } \\
\text { Manley ventilator } \\
\text { Fresh gas flow } 3 \text { litres } \mathrm{O}_{2} 6 \text { litres } \mathrm{N} . \mathrm{O} \\
\text { Tidal volume } 10 \mathrm{ml} / \mathrm{kg} \\
\text { measured with Wright Respirometer } \\
\text { Fentanyl } 0.05 \mathrm{mg}+ \\
\text { Atropine } 1.2 \mathrm{mg} \\
\text { Neostigmine } 2.5 \mathrm{mg}\end{array}$ & $\begin{array}{l}\text { Thiopentone } 250 \mathrm{mg} \\
\text { Suxamethonium } 75 \mathrm{mg} \\
4^{\circ} \text { "Lignocaine spray } \\
\text { Cuffed Magill Tube } \\
\text { Mapleson A circuit } \\
\text { Fresh gas flow } 3 \text { litres } \mathrm{O}_{2} \\
6 \text { litres N.O } \\
\text { Halothane } 1^{\prime \prime},\end{array}$ \\
\hline
\end{tabular}

*One patient whose weight was below $50 \mathrm{~kg}$ received papaveretum $15 \mathrm{mg}$ and

hyoscine $0.3 \mathrm{mg}$.
+ Two patients required a further $0.05 \mathrm{mg}$ fentanyl for pain as judged by tachycardiac rise in blood pressure, sweating, lacrimation, and dilatation of the pupils. 